\title{
СПІВЗАЛЕЖНА ПОВЕДІНКА ОСОБИСТОСТІ У КОНТЕКСТІ НАУКОВИХ ДОСЛІДЖЕНЬ
}

\author{
Діана Сушко \\ аспірант кафедри теоретичної і консультативної психології \\ Національний педагогічний університет імені М. П. Драгоманова, \\ 01601, Україна, м. Київ, вул. Пирогова, 9 \\ sushkodiana@ukr.net, https://orcid.org/0000-0002-4033-7818
}

\section{Анотація}

Статтю присвячено проблемі прояву співзалежної поведінки особистості в умовах сьогодення. На думку фахівців (психіатрів, наркологів, психологів, неврологів), профілактика та подолання співзалежності належить до актуальних медико-соціальних завдань. Ця проблема стає все гострішою у зв'язку із ростом поширеності залежності, зокрема, і хімічної, та інших видів адиктивної поведінки. Феномен співзалежності ще недостатньо вивчений у світі, в тому числі і в нашій країні. Про нього рідко згадується в посібниках з клінічної, вікової, сімейної, педагогічної психології. На сьогодні ні в медичній, ні в соціальній психології немає єдиного визначення поняття співзалежності, його лише описують як складний характерологічний феномен.

У статті обгрунтовано актуальність проблеми «співзалежності» як предмету наукового пошуку: вказано на необхідність визначення «співзалежності» як наукової категорії у соціальному і психологічному вимірах, дослідження «співзалежності особистості» як феномена психології; визначення особливостей прояву, критеріїв співзалежності особистості, умов і механізмів формування співзалежної поведінки; на потребу в розробці діагностичного комплексу, який дав би можливість різносторонньо дослідити вказаний феномен. В публікації розглянуті підходи до визначення поняття співзалежності у вітчизняній та зарубіжній літературі. Проаналізовано характерні особливості цього феномена на основі аналізу його трактування у працях психологів-науковців і практиків.

Автор пропонує розглядати співзалежність як надмірну патологічну емоційну залежність особистості від значущих для неї близьких, зумовлену низкою соціально-психологічних чинників, серед яких чільне місце займають виховання та відносини в батьківській сім'ї.

Ключові слова: співзалежність, особистість, розвиток, залежність, відносини, цінності, потреби.

\section{Вступ}

Співзалежність $є$ соціально поширеним явищем і головним фактором ризику формування залежної поведінки в осіб, від яких емоційно залежать співзалежні. Однак проблема співзалежної поведінки на сьогодні досліджена недостатньо. Винятково актуальним $є$ питання розробки та впровадження ефективних методів запобігання i психологічної корекції співзалежності.

Одним з головних показників, які характеризують державу, є здоров’я громадян. У цьому контексті треба підкреслити, що співзалежність негативно впливає як на життя конкретного індивіда, так і на суспільство загалом. 
Корекція співзалежної поведінки передбачає тривалий процес у зв’язку з наявністю певних усталених переконань, упереджених поглядів і сформованого стилю життя. До того ж, звільнення від співзалежності зустрічає опір середовища, що зумовлено наявними традиціями, упередженнями та стереотипами, які перешкоджають розвитку окремої особистості і суспільства загалом. Існує також проблема переходу такої «схильності» до співзалежних стосунків з покоління в покоління (Короленко, 2001).

Упродовж XX століття поняття «співзалежність» почало активно входити в науковий обіг, у певні напрями медицини i практичної психології, сферу міжособистісного спілкування. Феномен співзалежності як адикції відносин активно розглядався сучасними вітчизняними і зарубіжними авторами (А. Варга, М. Жидко, О. Смельянова, Ц. Короленко, Г. Коцюба, В. Крамченкова, Н. Манухіна, В. Москоленко, Б. Вайнхолд, Дж. Вайнхолд, Б. Бекнел, Дж. Фішер, М. Бітті та ін.). Вчені дотримуються позиції, що співзалежність $є$ найбільш поширеним розладом, що чинить негативний вплив на фізичне, емоційне здоров'я людини, іiі духовний стан і соціальний розвиток. Вони вказують, що співзалежність сприяє формуванню всіх залежностей: наркоманії, алкоголізму, трудоголізму, хімічної залежності, залежності від сексу, їжі тощо.

Однак, треба зазначити, що, не зважаючи на широке використання терміну «співзалежність», тривалу історію наукових диспутів щодо даного феномена, на сьогодні він залишається непізнаними у його розумінні багато спірних питань: немає єдиного теоретичного підходу до його трактування; недостатньо обгрунтовано поняття «співзалежності» як наукової категорії загалом, і «співзалежності особистості» зокрема; не визначено особливості прояву, чинники, умови та механізми формування співзалежності особистості; існує потреба у розробці діагностичного комплексу, який дав би можливість різностороннього дослідження цього феномена.

Мета дослідження полягає в окресленні теоретичних засад розуміння феномена співзалежності особистості у працях вітчизняних та зарубіжних науковців. Завдання дослідження: здійснити теоретичний аналіз сутності, чинників та особливостей прояву співзалежної поведінки у дорослому віці.

\section{Методи дослідження}

У дослідженні застосовувалися теоретичні методи, як от: аналіз, порівняння, систематизація, узагальнення теоретичного та емпіричного матеріалу.

\section{Результати та дискусії}

Термін «співзалежність» з'явився у професійному середовищі в кінці 1970-х років. Р. Саббі та Дж. Фріл в книзі «Співзалежність, невідкладна проблема» писали, що спершу це слово використовувалося для опису людини чи людей, чиє життя зазнало негативного впливу в результаті зв'язку з людиною, що має хімічну залежність. Співзалежний чоловік, дитина, коханець чи будь-які інші близькі того, хто має хімічну залежність, розглядалися як такі, що розвинули нездоровий шаблон поведінки, як реакцію на зловживання наркотиками чи алкоголем іншою людиною (як цитується у Битти, 2017).

Згідно з визначенням Б. Уайнхолд і Дж. Уайнхолд, співзалежність - це набута дисфункціональна поведінка, що виникає внаслідок незавершеності виконання одного або кількох завдань розвитку особистості в ранньому дитинстві (Уайнхолд \& Уайнхолд, 2002). 
На думку В. Москаленко, співзалежна людина повністю захоплена тим, щоб управляти поведінкою іншої людини, і зовсім не дбає про задоволення власних важливих життєвих потреб (Москаленко, 2015).

М. Бітті охарактеризувала співзалежного як людину, котра дозволила, щоб поведінка іншої людини впливала на неї, і повністю зайнята тим, аби контролювати дії іншого (інша людина може бути дитиною, дорослим, коханцем, чоловіком, батьком, матір'ю, сестрою, близьким другом, бабусею або дідусем, керівником, клієнтом, він може бути алкоголіком, наркоманом, хворим розумово чи фізично) (Битти, 2017).

Здебільшого автори сходяться на думці, що корені поведінки співзалежних лежать в дитинстві: сім'я співзалежних завжди дисфункціональна. А. Варга виокремила такі характеристики дисфункціональних сімей:

- негнучкість рольових функцій;

- негуманні правила, їх важко дотримуватися, виховання непослідовне;

- розмиті психологічні кордони членів родини;

- спілкування в сім’ї утруднено наявністю неконгруентних повідомлень, маніпуляцій;

- почуття не цінуються і не виражаються прямо;

- конфліктність у взаєминах; заохочується або бунтарство, або залежність і покірність.

Виховання в таких умовах формує ті психологічні особливості, які складають основу співзалежності, перш за все, це низька самооцінка та тривалі взаємини із залежною людиною (Варга, 2014).

М. Бітті, одна з найвідоміших дослідниць співзалежної поведінки, описала це явище як хворобу з таких причин:

- співзалежні реагують на такі хвороби як алкоголізм;

- співзалежність прогресує;

- співзалежна поведінка, зокрема, більшість саморуйнівних вчинків, стає звичною.

За словами авторки, співзалежні вважають себе відповідальними за весь світ та відмовляються взяти на себе відповідальність за власне життя (Битти, 2017).

В. Москаленко в своїх роботах вказала на недостатню вивченість згаданої проблеми і підсумувала, що співзалежність лише деякими фахівцями у сфері психічного здоров'я вважається хворобою та більше відповідає класифікації станів, причому без уточнення, яких саме станів. Феноменологічно співзалежність найбільше відповідає критеріям патологічного розвитку особистості; може бути компенсована за певних умов; охоплює всі сфери життя індивіда і прояви эї різноманітні. В. Москаленко зазначила: «Рятуючи хворого, співзалежні лише сприяють тому, що він буде продовжувати вживати алкоголь чи наркотики. Тоді співзалежні зляться на хворого. Спроба врятувати майже ніколи не вдається. Це лише деструктивна форма поведінки, деструктивна $\mathrm{i}$ для залежного, і для співзалежної людини» (Москаленко, 2017: 151).

У працях О. Смельянової співзалежність розглядається як емоційна залежність однієї людини від значущої для неї іншої. Так, автор чітко розмежовує розуміння здорових, зрілих стосунків, де, безперечно, є частка емоційної залежності, оскільки всі ми реагуємо на емоційний стан наших близьких, і стосунків співзалежних. В співзалежних стосунках простору для розвитку особистості практично немає. Співзалежний присвячує своє життя значущим близьким. Така людина живе не своїм життям, а життям своїх 
рідних. Співзалежні не відрізняють власних потреб від потреб тих, ким опікуються, кого контролюють, їх розвиток обмежується (Емельянова, 2016).

Так, О. Смельянова вважає, що поняття «володіння втратою», «зламане Я», «фрагментарне Я», «спустошене Я»- саме ті, що характеризують людей, які будують співзалежні відносини. На іiі думку, такі люди відчували природну для дитини залежність від ставлення до неї батьків або тих, хто їх заміщав. Кожен з них пережив дефіцит любові. Надто холодне і відчужене, надто критичне і зневажливе або занадто непослідовне ставлення батьків надломило крихке «Я», яке почало утворюватися на підставі зворотного зв'язку, який дитина отримувала від батьків. Внаслідок цього система уявлень про себе, самооцінка, була пошкоджена або спустошена у процесі іiі формування. Науковець стверджує, що кожна людина, що розвивається у такий спосіб, «володіє втратою» і тому вічно шукає любові, яка була необхідна і яку вона так і не змогла отримати, внаслідок чого «Я» як система уявлень про себе, як структура, покликана до побудови реальної картини світу, визначення місця людини в цьому світі і потрібна для врегулювання інстинктів, потреб та бажань $з$ реальними можливостями, виявляється порушеною (Емельянова, 2016).

На основі вказаного О. Смельянова робить висновки про те, що людина зі спустошеним «Я» прагне його заповнити з допомогою значущих близьких, що дозволяє їй досягти більш-менш комфортного почуття себе в соціумі. Оскільки власне «Я» такої людини було порушено в дитинстві, оскільки вона недоотримала любові, що потребувала, ставши дорослою, вона прагне відновити і заповнити своє «Я» через відносини 3 близькими. Тривожність, амбівалентність почуттів, які переживає така людина, робить їі прагнення до отримання любові значущих близьких і наповнення нею свого «Я» головною і нав’язливою метою іiі існування. Порожнеча в iï «Я», іiі самоцінці, самоусвідомленні потребує заповнення, інакше ії «Я» буде розчавлене зовнішнім або внутрішнім тиском. В екзистенційному сенсі для такої людини це питання виживання (Емельянова, 2016).

Згідно з науковою позицією Н. Бігун, у стосунках, позбавлених співзалежності, у партнерів завжди залишається достатньо місця для особистісного росту, задоволення власних потреб, досягнення особистих цілей. Такі люди більшою мірою самодостатні (Бігун, 2017).

Отже, беручи на себе відповідальність за почуття інших та контроль їхніх думок, співзалежні мають внутрішню впевненість у тому, що все, що відбувається зі значущими близькими, залежить від них. Оскільки відчуття контролю і необхідність бути потрібними закладається в поведінці співзалежних ще у процесі їхніх ранніх контактів з батьками, прищеплюється під впливом виховання. Саме тому в ситуаціях, коли людина не може реалізувати свою співзалежність (наприклад, розрив стосунків, розпад сім'ї, дорослішання дітей, їх сепарація тощо) виникає відчуття порожнечі і втрати сенсу життя. Цим пояснюється негайне прагнення таких людей створити нову сім'ю, еквівалентну колишній, де б можна було проявити себе в аналогічній ролі.

\section{Висновки}

Аналіз особливостей трактування феномена співзалежності у працях вищезгаданих науковців дозволяє зробити висновки про те, що співзалежність - це надмірна, патологічна емоційна залежність однієї людини від значущих для неї близьких. Під співзалежністю розуміються особистісні особливості, як-от, занижена самооцінка, нав'язливі думки, схильність до стійких упереджених суджень про себе, зовнішній світ, нераціональні почуття 
провини, сорому, страху, заперечення власних потреб, проблем, надмірний контроль поведінки оточуючих, залежність від чужої оцінки, нерозбірливість у зв’язках. Співзалежні більш схильні до залежності від алкоголю, наркотиків, ігроманії, сексуальних девіацій.

Отож, прояви співзалежної поведінки різноманітні. Вони впливають на всі сфери життя людини, iї світогляд, систему вірувань і цінностей, стосунки з оточуючими та на стан здоров'я. Перспективи подальших досліджень вбачаємо в емпіричному вивченні співзалежної поведінки особистості юнацького та дорослого віку.

\section{Література}

1. Битти, М. (2017). Спасать или спасаться? Как избавиться от желания постоянно опекать других и начать думать о себе. Москва : Издательство «Э».

2. Бігун, Н.І. (2017). Феномен самодостатності особистості у класичній психології. Науковий часопис НПУ імені М. П. Драгоманова. Серія 12. Психологічні науки, 6, 17- 25.

3. Варга, А.Я. (2014). Введение в системную семейную психотерапию. Москва : КогитоЦентр.

4. Емельянова, Е.В. (2016). Кризис в созависимых отномениях. Принципы и алгоритмы консультирования. Санкт-Петербург : Речь.

5. Короленко, Ц.П. \& Дмитриева, Н.В. (2001). Психосочиальная аддиктология. Новосибирск : Олсиб.

6. Москаленко, В.Д. (2015). Зависимость: Семейная болезнь. Москва : Институт консультирования и системных решений.

7. Москаленко, В.Д. (2017). Возвращение к жизни. Как спасти семью: конфликты, ссоры, алкоголизм, наркомания. Москва : Никея.

8. Уайнхолд, Б., \& Уайнхолд, Дж. (2002). Освобождение от созависимости. Москва : Класс.

9. Becnel, B.C. (1991). The co-dependent parent: Free yourself by freeing your child. San Francisco : HarperCollins.

10. Fischer, J.L., Spann, L., \& Crawford, D. (1991). Measuring Codependency. Alcoholism Treatment Quarterly, 8, 87-100. http://dx.doi.org/10.13072/midss.463

\section{References}

1. Bitti, M. (2017). Spasat' ili spasat'sya? Kak izbavit'sya ot zhelaniya postoyanno opekat' drugikh i nachat' dumat' o sebe [Save or save? How to get rid of the desire to constantly patronize others and start thinking about yourself]. Moscow : Izdatel'stvo «E» [in Russian].

2. Bigun, N.I. (2017). Fenomen samodostatnosti osobistosti u klasichnii psikhologiï [The phenomenon of self-sufficiency of specialty in classic psychology]. Naukovii chasopis NPU imeni M. P. Dragomanova. Seriya 12: Psikhologichni nauki - The scientific chronicle of NPU imeni M.P. Drahomanova. Seriya 12. Psychological sciences, 6, 17-25 [in Ukrainian].

3. Varga, A.Ya. (2014). Vvedenie v sistemnuyu semeinuyu psikhoterapiyu [Introduction to systemic family psychotherapy]. Moscow : Kogito-Tsentr [in Russian].

4. Emel'yanova, E.V. (2016). Krizis v sozavisimykh otnosheniyakh. Printsipy $i$ algoritmy konsul'tirovaniya [The crisis is in a dependent relationship. Principles and algorithms of counseling]. Sankt-Peterburg : Rech' [in Russian].

5. Korolenko, Ts.P. \& Dmitrieva, N.V. (2001). Psikhosotsial'naya addiktologiya [Psychosocial Addictology]. Novosibirsk: Olsib [in Russian].

6. Moskalenko, V.D. (2015). Zavisimost': Semeinaya bolezn' [Dependence: Family illness]. Moscow : Institut konsul'tirovaniya i sistemnykh reshenii [in Russian].

7. Moskalenko, V.D. (2017). Vozvrashchenie $k$ zhizni. Kak spasti sem'yu: konflikty, ssory, alkogolizm, narkomaniya [Back to life. How to save a family: conflicts, quarrels, alcoholism, drug addiction]. Moscow : Nikeya [in Russian]. 
8. Uainkhold, B., \& Uainkhold, Dzh. (2002). Osvobozhdenie ot sozavisimosti [Exemption from co-dependence]. Moscow : Klass [in Russian].

9. Becnel, B.C. (1991). The co-dependent parent: Free yourself by freeing your child. San Francisco : HarperCollins.

10. Fischer, J.L., Spann, L., \& Crawford, D. (1991). Measuring Codependency. Alcoholism Treatment Quarterly, 8, 87-100. http://dx.doi.org/10.13072/midss.463

\title{
CO-DEPENDENCY IN THE CONTEXT OF THE SCIENTIFIC RESEARCH Diana Sushko \\ Postgraduate of the Department of Theoretical and Counselling Psychology \\ National Pedagogical Dragomanov University \\ 9, Pyrohov Str., Kyiv, Ukraine, 01601 \\ sushkodiana@ukr.net, https://orcid.org/0000-0002-4033-7818
}

\begin{abstract}
Absract
The article is devoted to the actual problem of manifestation of co-dependent personality behavior in the present conditions. The problem of co-dependency analyzed by various specialists (psychiatrists, narcologists, psychologists, neurologists) is included in the list of serious medical and social aspects. This problem is becoming more and more urgent due to the increasing scale of dependence, including chemical, and other addictive behavior. The phenomenon of co-dependency has not been sufficiently studied in the world, including our country. It is rarely mentioned in manuals of clinical, age, family, pedagogical psychology.

The article substantiates the relevance of the problem «co-dependency» as a subject of scientific research: the need to define «co-dependency» as a scientific category in social and psychological dimensions, the study of "co-dependency of personality» as a phenomenon of psychology; determination of characteristics of manifestation, criteria of co-dependency of personality, conditions and mechanisms of formation of co-dependent behavior; the need to develop a diagnostic complex that would allow us to investigate this phenomenon in various ways. The approaches to defining the concept of co-dependency in domestic and foreign literature are considered in the publication. The characteristic features of this phenomenon from the point of view of psychology and sociology are analyzed on the basis of the review of features of its interpretation in the works of scientists and practitioners. Today, neither medical nor social psychologists give a single definition of the concept of co-dependency, it is only described as a complex characterological phenomenon.

The author proposes to consider co-dependency as an excessively pathological emotional dependence of the individual on significant relatives, due to a number of psycho-social factors, among which the most important are upbringing and relationships in the parent family.
\end{abstract}

Keywords: co-dependency, personality, development, dependence, relationships, values, needs.

Подано 10.12.2019

Рекомендовано до друку 20.12.2019 